\title{
Proteomic characterization of the Rph15 barley resistance gene-mediated defence responses to leaf rust
}

Letizia Bernardo ${ }^{1}$, Bhakti Prinsi ${ }^{2}$, Alfredo Simone Negri ${ }^{2}$, Luigi Cattivelli ${ }^{1}$, Luca Espen ${ }^{2}$ and Giampiero Valè ${ }^{1,3^{*}}$

\begin{abstract}
Background: Leaf rust, caused by the biotrophic fungal pathogen Puccinia hordei, is one of the most important foliar disease of barley (Hordeum vulgare) and represents a serious threat in many production regions of the world. The leaf rust resistance gene Rph15 is of outstanding interest for resistance breeding because it confers resistance to over 350 Puccinia hordei isolates collected from around the world. Molecular and biochemical mechanisms responsible for the Rph15 effectiveness are currently not investigated. The aim of the present work was to study the Rph15-based defence responses using a proteomic approach.

Results: Protein pattern changes in response to the leaf rust pathogen infection were investigated in two barley near isogenic lines (NILs), Bowman (leaf rust susceptible) and Bowman-Rph15 (leaf rust resistant), differing for the introgression of the leaf rust resistance gene Rph15. Two infection time points, 24 hours and four days post inoculation (dpi), were analysed. No statistically significant differences were identified at the early time point, while at 4 dpi eighteen protein spots were significantly up or down regulated with a fold-change equal or higher than two in response to pathogen infection. Almost all the pathogen-responsive proteins were identified in the Bowman-Rph15 resistant NIL. Protein spots were characterized by LC-MS/MS analysis and found to be involved in photosynthesis and energy metabolism, carbohydrate metabolism, protein degradation and defence. Proteomic data were complemented by transcriptional analysis of the respective genes. The identified proteins can be related to modulation of the photosynthetic apparatus components, re-direction of the metabolism to sustain defence responses and deployment of defence proteins.

Conclusions: The identification of leaf rust infection-modulated defence responses restricted to the resistant NIL support the hypothesis that basal defence responses of Bowman, but not the Rph15 resistance gene-based ones, are suppressed or delayed by pathogen effectors to levels below the detection power of the adopted proteomic approach. Additionally, Rph15-mediated resistance processes identified mainly resides on a modulation of primary metabolism, affecting photosyntesis and carbohydrate pool.
\end{abstract}

Keywords: Barley, Leaf rust, Resistance gene, Rph15, Proteomics, Near isogenic lines

\footnotetext{
* Correspondence: giampiero.vale@entecra.it

${ }^{1}$ CRA-Consiglio per la ricerca e la sperimentazione in agricoltura, Genomics

Research Centre, Via S. Protaso 302, Fiorenzuola d'Arda, PC I-29017, Italy

${ }^{3}$ CRA-Consiglio per la ricerca e la sperimentazione in agricoltura, Rice

Research Unit, S.S. 11 to Torino, Km 2,5, Vercelli 13100, Italy

Full list of author information is available at the end of the article
} 


\section{Background}

The fungus Puccinia hordei is a biotrophic pathogen causal agent of leaf rust, a serious leaf disease of barley worldwide. This pathogen causes serious economic losses with yield reductions by up to $62 \%[1,2]$ and adversely affects grain quality by reducing grain weight and increased levels of undesirable protein in the barley growing region of the world [3]. Rust fungi have a complex life cycle that involves two parasitic stages, dikaryotic and monokaryotic [4]. The dikaryotic stage is the form causing rust disease by attacking mesophyll tissues until pathogen injures the epidermis to release urediospores [5].

Barley resistance to leaf rust pathogens is governed by major resistance (R) genes ( $R p h$ genes) that are race-specific. Most $R p h$ genes confer complete seedling resistance associated with necrosis (or hypersensitive response, HR) of the plant cells attacked by the pathogen sporelings [6], while some $R p h$ resistance genes confer incomplete resistance, in which the fungus forms small uredinia surrounded by chlorotic or necrotic plant tissues. This second resistance type is a non-HR (nonhypersensitivity resistance) polygenically inherited leaf rust resistance, which was termed "partial resistance" and is not associated with plant cell necrosis [7]. Several seedling resistance genes were identified from cultivated and wild barley, of which 19 were designed Rph1 to Rph19 [8]. The resistance provided by single $R p h$ genes has often been overcome by new pathotypes, believed to have arisen after gene mutations. As a direct consequence, the number of effective Rph genes available to breeders is decreasing rapidly, suggesting the need for a new gene deployment strategy [9]. The leaf rust resistance gene Rph15, located on chromosome 2HS [1], was derived from PI 355447, an accession of wild barley (Hordeum vulgare subsp. spontaneum) collected in Israel. When evaluated for its reaction toward a worldwide collection of over $350 \mathrm{P}$. hordei isolates, it conferred resistance to all but the isolates 90-3, from Israel. Rph 15 is one of the most broadly effective resistance genes and it is therefore useful in barley breeding programs for leaf rust resistance.

Barley interaction with the leaf rust pathogen represents a model to understand the molecular basis of both race-specific and partial resistance. Molecular basis of partial resistance were recently investigated using eQTL (expression Quantitative Trait Loci) analyses carried out in P. hordei infected doubled haploid lines and QTLNILs (QTL-Near Isogenic Lines) [10,11]. These studies provided an overview of the responsive dynamic defence process and identified several candidate genes as being co-localized with the phenotypic QTL. No additional published microarray studies were dedicated to barley- $P$. hordei interaction.
In addition to transcriptional studies, proteomic techniques can provide insight into the molecular mechanisms underpinning resistance gene-based plant defence responses. The compatible interaction between wheat and the leaf rust pathogen $P$. triticina was investigated at 3, 6 and 9 dpi (days post inoculation) and only at the latter time point of inoculation seven plant proteins involved in translation and stress responses were identified as pathogen-responsive [12]. No published proteomic studies have been performed on barley leaves infected with leaf rust.

In this work, barley responses to leaf rust infection were investigated, in two barley near isogenic lines differing for the introgression of the broad effective leaf rust resistance gene $R p h 15$. A proteomic study was performed at early (24 hours) and late (4 dpi) infection times and, after analysis of protein pattern changes, it was observed that only at the late time points and in the resistant NIL differential protein accumulation occurs in response to pathogen inoculation. The differentially expressed proteins were involved in photosynthesis, carbon metabolism, defence responses and secondary metabolism.

\section{Results and discussion}

\section{Experimental design and 2-DE analysis}

In this study, the defence responses to leaf rust of two near-isogenic barley lines, Bowman and Bowman-Rph15 differing for the presence/absence of the broad effective leaf rust resistance gene $R p h 15$, were investigated using a proteomic approach. The utilization of NILs allows to relate the pathogen-responsive changes in protein accumulation observed between the two NILs to the resistance gene activity. Two time points of inoculation were selected for the analyses. At the first time point investigated, 24 hours post inoculation (hpi), bibliographic data report that the leaf rust pathogen has established haustoria in the mesophyll cells and has started intercellular hyphal growth [13,14; Brian J. Steffenson, personal communication]. At 4 days post inoculation (dpi), the number of cells with established haustoria is higher than at 24 hpi and hyphae completed their intercellular growth. Since infection conditions applied in the present work are basically the same as those previously reported $[13,14]$, we assumed that in our experiments the differentiation of infection structures and colonization process followed the same timing as described above. In agreement with previous observations, no disease symptoms were observed in both the NILs at $24 \mathrm{hpi}$, while at $4 \mathrm{dpi}$ few chlorotic areas were observed in the susceptible NIL Bowman only (Figure 1A). In order to assess the success of the inoculation process, single plants of each biological replicate were left until $8 \mathrm{dpi}$. At this stage sporulating colonies were observed in Bowman while 

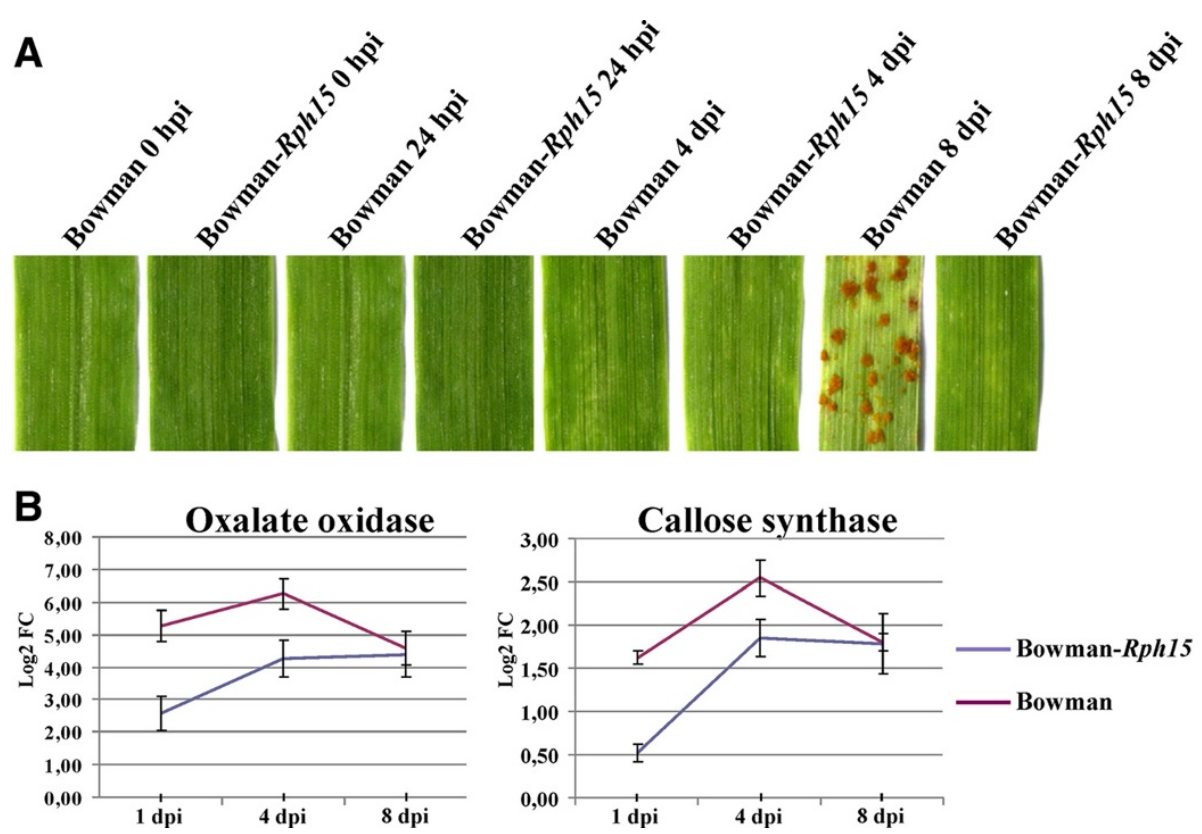

Figure 1 Phenotype and defense genes activation of barley leaves subjected to proteomic analyses. (A) Barley leaves images of the two NILS Bowman and Bowman-Rph15 inoculated with the leaf rust pathogen at the indicated time points and utilized for the proteomic analyses. After sampling, in some plants for each biological replicate the disease was left to proceed until $8 \mathrm{dpi}$ to assess the success of the infection experiments. (B) The same genotypes and time points of inoculation as in (A) were verified for the transcriptional activation of the defense related genes coding for oxalate oxidase and callose synthase using quantitative RT-PCR analysis. Normalization was carried out with the $\beta$-actin constitutively expressed gene. Values are expressed as log2 fold changes of transcript levels in the inoculated samples with respect to the transcript levels in un-inoculated barley leaves. Error bars represent SD across all RT-PCR replicates (three from each of two independent inoculations). Statistical significance of differential expression was evaluated with a Wilcoxon two group test ( $\mathrm{P}<0.05$, Methods).

Bowman-Rph15 exhibited only few chlorotic areas. To further verify that defence responses were properly deployed in the infected leaves used for proteomic analyses, quantitative RT-PCRs were conducted on genes encoding for oxalate oxidase, an $\mathrm{H}_{2} \mathrm{O}_{2}$ generating enzyme [15], and callose synthase, an enzyme involved in cell wall reinforcement [16]. For both genes expression was significantly increased by inoculation at 1 and 4 dpi $(\mathrm{P}<0.05$, Methods) and was unresponsive by $8 \mathrm{dpi}$, with higher transcription level in Bowman compared to BowmanRph15 (Figure 1B). These results demonstrate that active defence responses were triggered in both the genotypes at the inoculation time points used to detect leaf rust infection-dependent changes in protein accumulation.

Proteins obtained from the two infection time points were subjected to the proteomic analysis and three technical replicates were performed for each of two biological replicates. In the 2-DE maps, an average of 850 protein spots were visualized with the SYPRO Ruby fluorescent staining. After image and statistical analyses, no significantly differentially accumulated proteins were identified at 24 hpi in both genotypes (data not shown). In agreement with our results, no changes in protein accumulation were also detected at $3 \mathrm{dpi}$ in the interaction between the leaf rust pathogen $P$. triticina and a susceptible wheat line [12]. Nevertheless, it is important to observe that at $18 \mathrm{hpi}$ more than 1000 genes were differentially expressed in barley leaves of genotypes carrying QTLs for partial resistance to $P$. hor$d e i$ in accordance with an active defence response at this infection time $[10,11]$. These findings underline, as expected, that a longer time is required to detect the response at protein level. Moreover, because of the proteomic approach adopted, only a part of the proteome was investigated in this study and this do not permit a satisfactory comparison between transcriptomic and proteomic data.

Figure 2 reports 2-DE representative maps of proteins isolated from both the Bowman and the Bowman-Rph15 in mock-inoculated and leaf rust inoculated conditions at $4 \mathrm{dpi}$. Eighteen protein spots showing significant differential accumulation in response to pathogen infection were identified at $4 \mathrm{dpi}$; differential accumulation was claimed only for spots in which normalized volumes of six replicates for each condition was showing an average fold change in their relative volumes of at least two folds (Table 1; Figures 2 and 3). In the susceptible NIL (Bowman) at 4 dpi only a few differences were detectable (Figure 2 A vs 2 B). In particular, two spots (2333 and 3150) were more abundant and one spot (2613) was less 

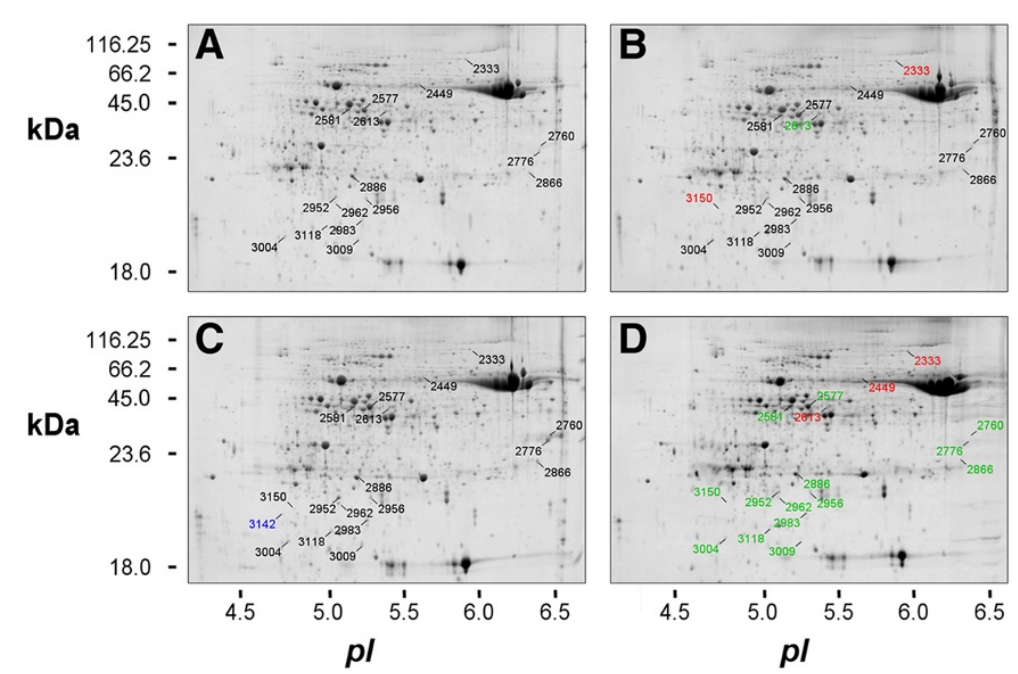

Figure 2 2-DE maps. Representative 2-DE maps of soluble protein fractions extracted from Bowman and Bowman-Rph15 leaves at 4 days after mock inoculation (A and $\mathbf{C}$, respectively) or after inoculation with leaf rust spores (B and $\mathbf{D}$, respectively). Proteins (300 $\mu \mathrm{g}$ ) were analyzed by IEF at pH 4-7, followed by 12.5\% SDS-PAGE and visualized by SYPRO-staining. Numbers, corresponding to those in Table 1 and Figure 3, indicate the spots, identified by LC-ESI-MS/MS, showing significant changes of at least two-fold in their relative volumes (t-test, $p<0.05)$ after 4 dpi. Proteins that increased or decreased after this treatment are reported in red or in green, respectively. Spot 3142 is highlighted in blue, indicating its absence in the Bowman-Rph15 inoculated sample.

abundant in the rust inoculated sample with respect to the mock inoculated one. In the resistant NIL (BowmanRph15) a total of 15 spots were significantly down accumulated or absent (spot 3142) in the inoculated samples with respect to its control, while the levels of three protein spots rose in the inoculated sample with respect to the control condition (Figure $2 \mathrm{C}$ vs $2 \mathrm{D}$ ).

\section{Identification of Rph15-resistance gene-related proteins}

The 18 spots (Table 1 and numbers in Figures 2 and 3) of interest were characterized by LC-ESI-MS/MS. The differentially modulated proteins could be grouped into the following five different functional classes: photosynthesis and energy metabolism, carbohydrate metabolism, protein biosynthesis and degradation, defence responses and secondary metabolism.

\section{Photosynthesis and energy metabolism}

Twelve of the identified proteins corresponded to photosynthetic or chloroplast-related proteins, including $\mathrm{Ru}$ BisCo large chain (RuLC) and RuBisCo activase, while one spot represented an ATP synthase protein (spot number 3004).

RuBisCo is the most expressed protein in leaves, with about $30 \%$ of total leaf proteins $[17,18]$ and an increase of $\mathrm{RuBisCO}$ degraded forms was generally observed in wheat leaves after Fusarium graminearum infection [19]. Many spots were identified in the present work as degradation products of RuLC; the experimental molecular weights were significantly lower than their theoretical values (Table 1), thus indicating a degradation of RuLC in the samples analyzed [20,21]. Degradation of photosynthetic apparatus may contribute to restrict pathogen growth into barley cells by promoting the activation of defences in non-infected cells because small peptide and amino acids derived from degradation can be directed to other metabolic pathways involved in defence [22,23]. We observed higher levels of RuLC fragments in the control samples than in the inoculated tissues of Bowman-Rph15, supporting that turnover of RuLC was markedly reduced in this genotype after infection. Interestingly, no statistically significant differences in RuLC fragments accumulation were observed between control and inoculated conditions in Bowman. To confirm the proteomics data, a Western blot analysis using an anti RuLC antibody was performed on the protein extracts of the two NILs under control and inoculated conditions (Figure 4). Results from this experiment support a reduction of RuLC degraded forms (indicated as numbers 1 to 5 in Figure 4A) occurring on infected Bowman-Rph15 with respect to control tissues. In Bowman-Rph15 inoculated sample was in fact evaluated a reduction of $38.2 \%, 84.1 \%, 75.28 \%$ and $10.12 \%$ of the RuLC degraded forms with respect to the control sample respectively for the major bands of the degradation forms numbered from 1 to 5 (Figure 4B). A similar RuLC degradation trend was observed in rice as induced by bacterial blight infection, in lesion mimic mutants [24-26] and in wheat after Fusarium graminearum infection [19]. Taken together, our results support the conclusion that 
Table 1 List of the 18 spots identified by LC-ESI-MS/MS whose concentration is modulated by leaf rust infection in barley leaves

\begin{tabular}{|c|c|c|c|c|c|c|c|c|}
\hline Spot ID & Accession number & Species & Protein description & $E C$ & $A b b$. & $M_{r}{ }^{a} / p l^{a}$ & $M_{r}{ }^{b} /\left.p\right|^{b}$ & Cov. (\%) ${ }^{c}$ \\
\hline \multicolumn{9}{|c|}{ Photosynthesis and energy metabolism } \\
\hline 2577 & Q40073 & Hordeum vulgare & $\begin{array}{l}\text { Ribulose bisphosphate } \\
\text { carboxylase/oxygenase } \\
\text { activase } A \text {, chloroplastic }\end{array}$ & & RuACS (b) & $40.2 / 5.3$ & $46.1 / 5.6^{e}$ & $43.5^{\mathrm{e}}$ \\
\hline 2581 & Q40073 & Hordeum vulgare & $\begin{array}{l}\text { Ribulose bisphosphate } \\
\text { carboxylase/oxygenase } \\
\text { activase A, chloroplastic }\end{array}$ & & RuACS (c) & $40.8 / 5.2$ & $46.1 / 5.6^{e}$ & $34.6^{\mathrm{e}}$ \\
\hline 2760 & P05698 & Hordeum vulgare & $\begin{array}{l}\text { Ribulose bisphosphate } \\
\text { carboxylase large chain }\end{array}$ & 4.1.1.39 & RuLC & $25.4 / 6.4$ & $52.9 / 6.2^{e}$ & $16.3^{\mathrm{e}}$ \\
\hline 2776 & P05698 & Hordeum vulgare & $\begin{array}{l}\text { Ribulose bisphosphate } \\
\text { carboxylase large chain }\end{array}$ & 4.1.1.39 & RuLC & $24.2 / 6.4$ & $52.9 / 6.2^{e}$ & $22.6^{e}$ \\
\hline 2866 & P05698 & Hordeum vulgare & $\begin{array}{l}\text { Ribulose bisphosphate } \\
\text { carboxylase large chain }\end{array}$ & 4.1.1.39 & RuLC & $22.3 / 5.2$ & $52.9 / 6.2^{e}$ & $8.0^{\mathrm{e}}$ \\
\hline 2952 & P05698 & Hordeum vulgare & $\begin{array}{l}\text { Ribulose bisphosphate } \\
\text { carboxylase large chain }\end{array}$ & 4.1.1.39 & RuLC & $21.3 / 5.1$ & $52.9 / 6.2^{e}$ & $9.0^{\mathrm{e}}$ \\
\hline 2983 & P05698 & Hordeum vulgare & $\begin{array}{l}\text { Ribulose bisphosphate } \\
\text { carboxylase large chain }\end{array}$ & 4.1.1.39 & RuLC & $20.1 / 5.3$ & $52.9 / 6.2^{e}$ & $4.6^{e}$ \\
\hline 3004 & XP_002465461 & Sorghum bicolor & ATP synthase $\beta$ chain ${ }^{d}$ & & ATPase $\beta$ & $19.4 / 4.1$ & $22.8 / 5.3$ & 6.1 \\
\hline 3009 & P05698 & Hordeum vulgare & $\begin{array}{l}\text { Ribulose bisphosphate } \\
\text { carboxylase large chain }\end{array}$ & 4.1.1.39 & RuLC & $19.2 / 5.2$ & $52.9 / 6.2^{e}$ & $4.2^{e}$ \\
\hline 3118 & P05698 & Hordeum vulgare & $\begin{array}{l}\text { Ribulose bisphosphate } \\
\text { carboxylase large chain }\end{array}$ & 4.1.1.39 & RuLC & $19.7 / 5.0$ & $52.9 / 6.2^{e}$ & $6.9^{e}$ \\
\hline 3142 & P05698 & Hordeum vulgare & $\begin{array}{l}\text { Ribulose bisphosphate } \\
\text { carboxylase large chain }\end{array}$ & 4.1.1.39 & RuLC & $20.4 / 4.7$ & $52.9 / 6.2^{e}$ & $4.4^{\mathrm{e}}$ \\
\hline 3150 & P05698 & Hordeum vulgare & $\begin{array}{l}\text { Ribulose bisphosphate } \\
\text { carboxylase large chain }\end{array}$ & 4.1.1.39 & RuLC & $20.7 / 4.8$ & $52.9 / 6.2^{e}$ & $4.8^{e}$ \\
\hline \multicolumn{9}{|c|}{ Carbohydrate metabolism } \\
\hline 2333 & CAZ64535 & Hordeum vulgare & Sucrose synthase & 2.4.1.13 & SuSy & $88.2 / 5.9$ & $92.2 / 5.8$ & 18.4 \\
\hline 2962 & CAC32847 & Hordeum vulgare & $\begin{array}{l}\text { Adenosine diphosphate } \\
\text { glucose } \\
\text { pyrophosphatase }\end{array}$ & & AGPPase & $21.0 / 5.1$ & $19.5 / 5.7^{e}$ & $17.4^{\mathrm{e}}$ \\
\hline \multicolumn{9}{|c|}{ Protein degradation } \\
\hline 2449 & XP_002454700 & Sorghum bicolor & $\begin{array}{l}\text { Leucine aminopeptidase } 2 \text {, } \\
\text { chloroplastic }\end{array}$ & 3.4.11.1 & LAP 2 & $57.0 / 5.6$ & $61.8 / 7.6$ & 20.0 \\
\hline \multicolumn{9}{|c|}{ Defence responses } \\
\hline 2886 & CAA55345 & Hordeum vulgare & chitinase & 3.2.1.14 & $\mathrm{CHI}$ & $22.3 / 5.2$ & $26.6 / 6.1$ & 29.4 \\
\hline 2956 & BAD31057 & Oryza sativa & Chitinase III-like protein & & $\mathrm{CHI} I I I$ & $21.2 / 5.3$ & $18.9 / 6.5$ & 12.7 \\
\hline \multicolumn{9}{|c|}{ Secondary metabolism } \\
\hline 2613 & CAA54616 & Hordeum vulgare & $\begin{array}{l}\text { Flavonoid } \\
\text { 7-0-methyltransferase }\end{array}$ & 2.1 .1 .6 & F-OMT & $39.2 / 5.4$ & $42.3 / 5.4$ & 29.5 \\
\hline
\end{tabular}

Statistical information about LC-ESI-MS/MS analysis are reported in Additional files 1 and 2.

Abb.: abbreviation.

a: experimental molecular weight and $\mathrm{pl}$.

b: theoretical molecular weight and $\mathrm{pl}$.

c: amino acid coverage (\%).

$\mathrm{d}$ : annotation obtained by BLAST-P alignment analysis against the Viridiplantae subset of the nr-database at NCBI.

e: value referred to the mature form of the protein.

in the resistant genotype Bowman-Rph15 the Rubisco integrity was more preserved after infection with respect to control sample.

RuBisCo activase (RuACS) regulates RuBisCo activity by hydrolysing ATP to promote the dissociation of inhibitory sugar phosphates [27]. RuACS accumulation is reduced in the Bowman-Rph15 NIL infected sample (protein spots numbers 2577, 2581) (Figure 3). In the susceptible NIL Bowman, no substantial alterations of RuLC and RuACS were observed. It can be hypothesized 

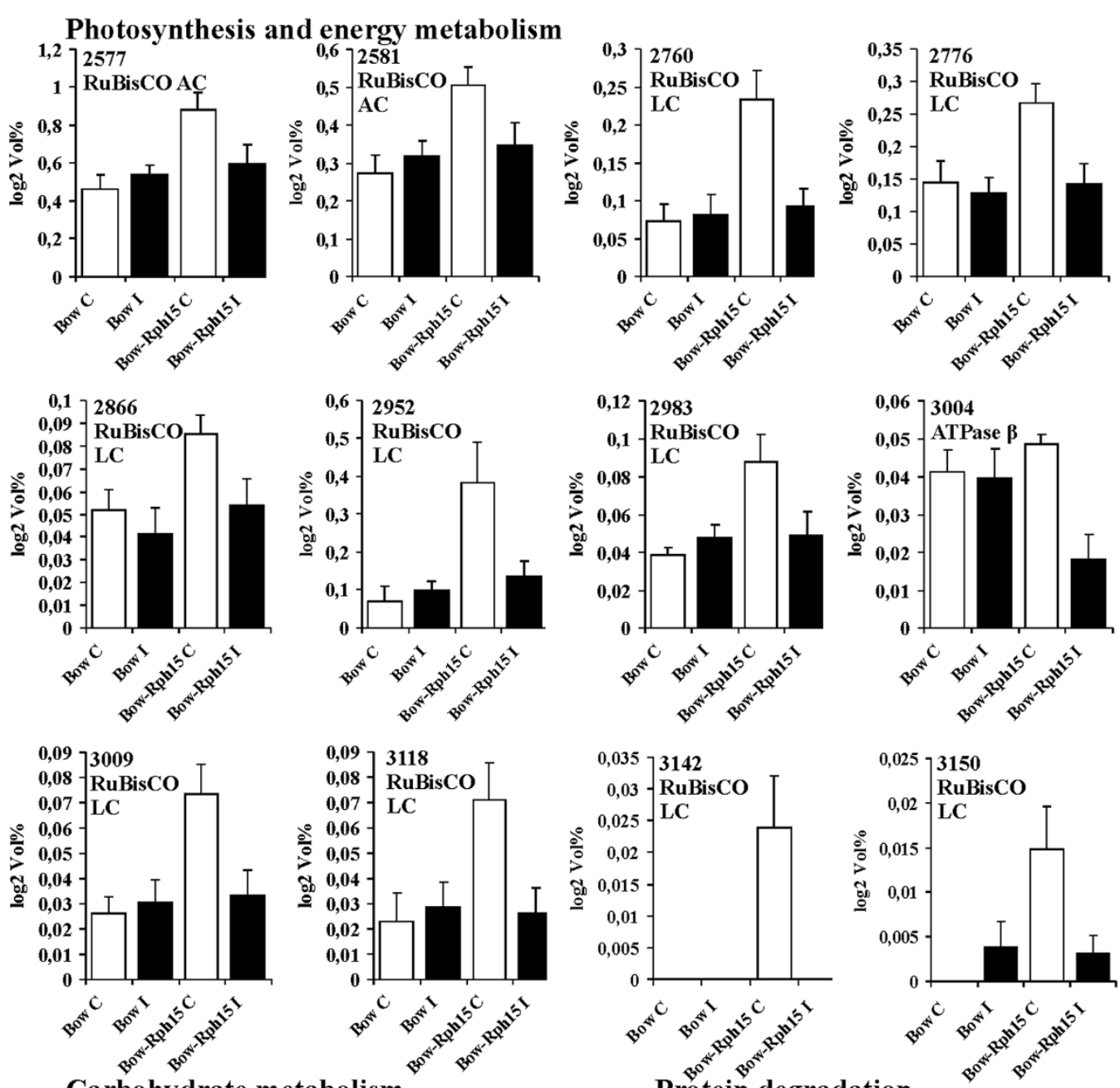

Carbohydrate metabolism
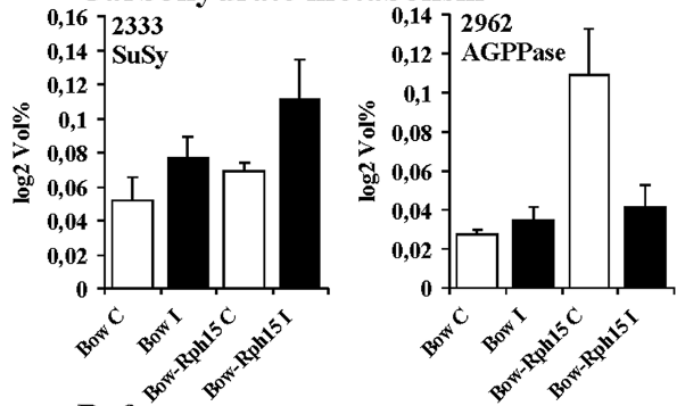

Protein degradation

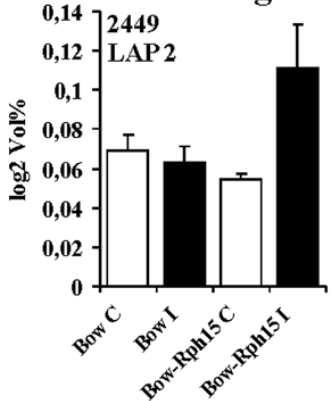

\section{Defence responses}
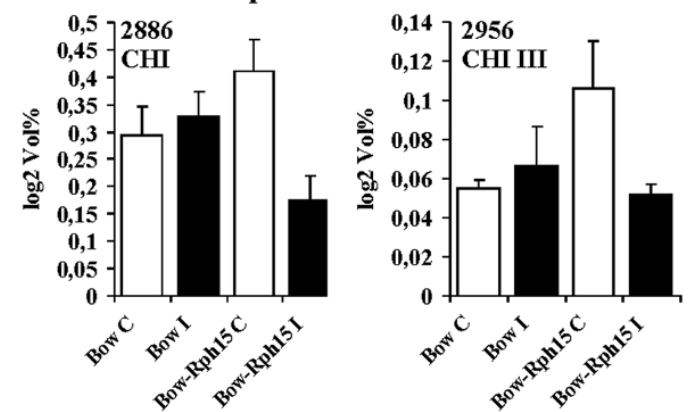

\section{Secondary metabolism}

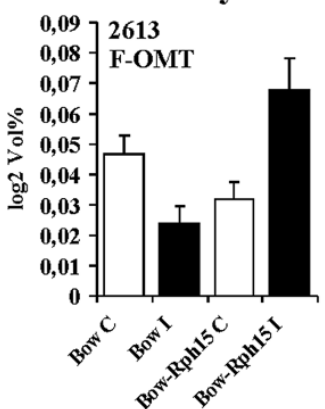

Figure $\mathbf{3}$ (See legend on next page.) 
(See figure on previous page.)

Figure $\mathbf{3}$ Changes in protein accumulation in the two NILs in response to leaf rust infection. Changes in the relative volumes of the identified proteins whose concentration is increased or decreased in the two NILs Bowman (Bow) and Bowman-Rph15 (Bow-Rph15) at 4 days after mock inoculation (C) or after inoculation with leaf rust spores (I). Values are the means of six 2-DE gels derived from two independent biological replicates analyzed in triplicate $(n=6)$. Error bars represent SD across all replicates. Numbers identify the spots as indicated in Table 1 and Figure 2; proteins were ordered into five functional classes, as indicated in Table 1.

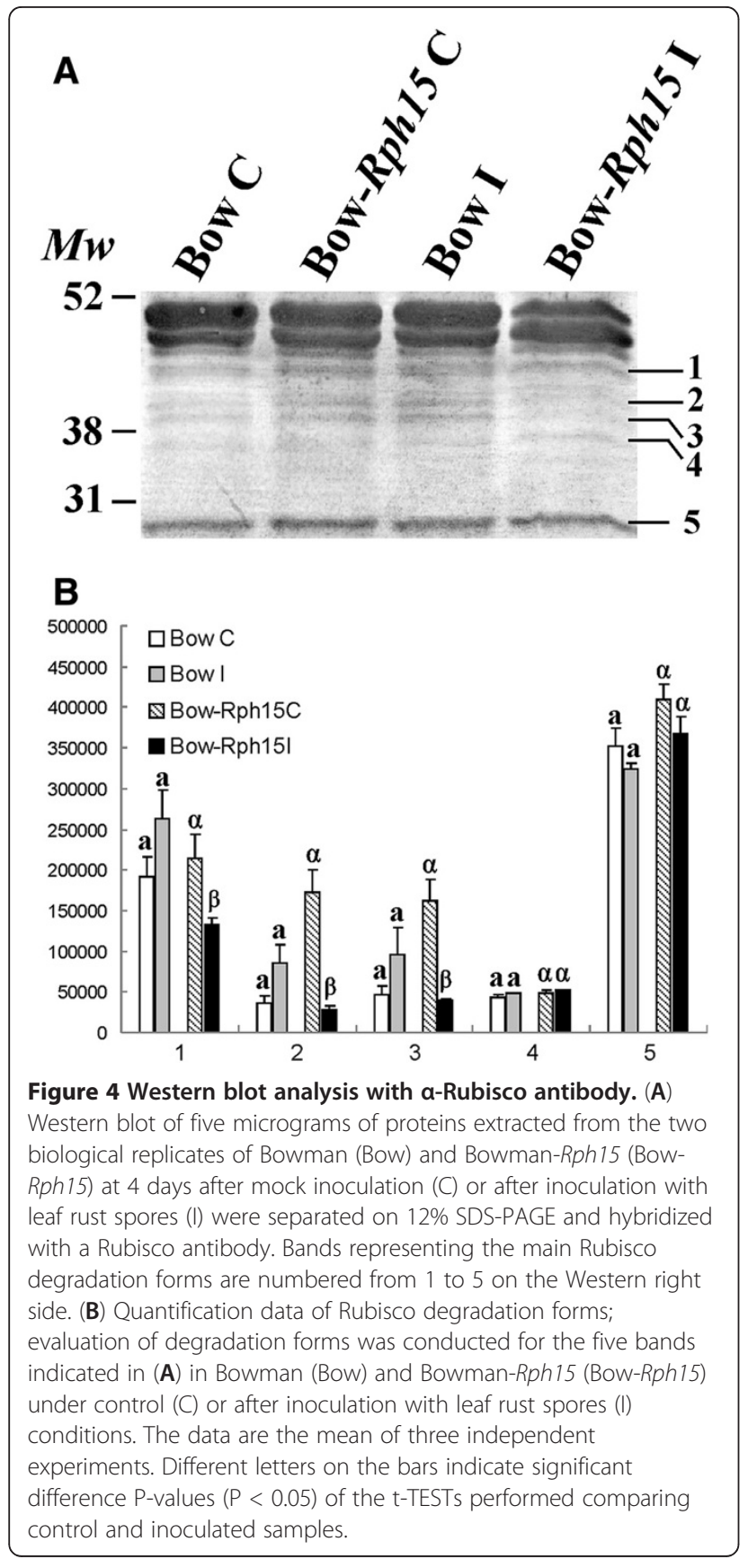

that this effect on RuACS is linked to a different strategy to modulate the phothosynthesis in Bowman-Rph15, the genotype in which the pathogen negatively affect $\mathrm{Ru}$ BisCo degradation.

Spot 3004 represents an ATP-synthase $\beta$ chain. This protein is involved in photosynthesis and oxidative respiration to drive synthesis of ATP in chloroplasts and mitochondria [28]. Accumulation of this protein was down-regulated after infection in the resistant NIL only (Figure 3). A decrease of proteins related to carbon metabolism and photosynthesis that include RuLC, RuACS and ATP synthase has been also observed in orange (Citrus sinensis) leaves after infection with the biotrophic bacterial pathogen Xanthomonas citri pv. citri [29]. Similarly, a down regulation of ATP-synthase subunits was observed in grape (Vitis vinifera) response to Flavescence dorée infection [30]. Similar observations were obtained at the transcriptomic level for barley leaves infected with the biotrophic powdery mildew fungus [31] and after an extensive analysis of the effects on photosynthetic genes of several biotic stresses in eight plant species [32]. These investigations suggest that a slow turnover of many photosynthetic proteins represent an adaptive consequence resulting in reduced energy supply when plants are facing a biotic attack and require to re-direct resources in immediate defence needs $[27,32,33]$. The reduced accumulation of these three proteins in the resistant NIL is therefore possibly consistent with a re-direction of the metabolism to fuel defence responses. Nevertheless, down accumulation of RuLC, RuACS and ATP synthase proteins was also observed in the leaves of rice spotted leaf 6 mutants that undergo to spontaneous programmed cell death (PCD), caused by oxidative burst and membrane damage, in the absence of pathogen infection [18]. Since the Rph15 resistance most likely involves an HR-dependent PCD response, similarly to that of most $R p h$ genes conferring complete resistance [6], it cannot be excluded that the downregulation of photosynthetic proteins observed in the resistant NIL could also depend from cellular damage caused by the HR response.

An higher accumulation of RuLC degraded forms was observed for Bowman-Rph15 with respect to Bowman in the control samples (Figure 3). Also for RuACS and AGPPase, higher accumulation was present in BowmanRph15 than in Bowman control samples. Conversely, this behaviour was not observed for several other protein 
spots (i.e. Susy, LAP2, OMT, ATPase $\beta$, see below), indicating a process specific for proteins involved in the photosynthetic apparatus. Since data are deriving from six replicates for each experiment (with two biological replicates) and SD detected for these proteins was low, it can be postulated that the observed trend represents a genuine differential accumulation among Bowman and Bowman-Rph15 control samples ascribable to an unknown alteration of the cellular homeostasis orchestrated by the $R p h 15$ resistance gene or by another tightly associated sequence.

\section{Carbohydrate metabolism}

Two infection-modulated proteins identified in this study are related to sugar metabolism: sucrose synthase (SuSy, EC. 2.4.1.13) and adenosine diphosphate glucose pyrophosphatase (AGPPase). SuSy accumulation was significantly increased in infected leaves of the resistant NIL (spot 2333 in Table 1; Figures 2 and 3). SuSy catalyzes the reversible reaction from sucrose to fructose and UDP-glucose and an increase in this activity usually results in decreased starch biosynthesis. In addition, SuSy is the key enzyme of symplastic sucrose unloading and in concert with invertases, it can modulate the sink capacity of plant tissues [34]. SuSy has a dual role in producing both cytosolic ADPG, directed to starch biosynthesis, and UDPG, necessary for cell wall material and glycoprotein biosynthesis [35]. Defense-related SuSy activity may serve to allocate sucrose into callose deposition and other carbohydrate-consuming defense reactions, as supported by the observation of an increased SuSy activity in the resistant response of tobacco plants to Phytophthora nicotianae [36] and in several other plant-pathogen interactions (reviewed in [37]). A leaf rust infection-dependent induction of a callose synthase gene was observed in the present work (Figure 1B), suggesting re-directioning of sugars to structural components of the cell wall to constitute physical barriers to the infection.

A consistent decrease in ADP-glucose pyrophosphatase (AGPPase) abundance (spot 2962 in Figures 2 and 3) was observed in infected tissues of the resistant genotype only. AGPPase catalyzes ADP-glucose breakdown to produce AMP and G1P, and its reduced accumulation/activity drastically lead to a reduction in starch biosynthesis [38,39].

There are increasing evidences that the availability of soluble carbohydrates is a major factor in determining plant resistance to infections. The results of plantpathogen interactions also depend on the rapid mobilization of carbohydrates and on the reprogramming of the carbon flow from sucrose to hexoses [36]. The data about SuSy and AGPPase suggest that in the resistant genotype under infection there could be a redirection of primary metabolism that leads to a reduction of starch biosynthesis in order to provide a strong supply to the hexoses pool. To further verify the role of sugar metabolism in Rph15-mediated response to leaf rust, an evaluation of reducing sugars and sucrose was conducted on control and inoculated conditions in both NILs (Bowman and Bowman-Rph15) (Table 2). While sucrose content was not affected by infection, reducing sugars were slightly but significantly increased (of about $12 \%$ ) by inoculation in the resistant NIL and significantly decreased in the susceptible one. The reducing sugars increase supports a re-direction of the hexoses pool to defence pathways activated in the resistant NIL in response to the leaf rust pathogen infection.

\section{Protein degradation}

Protein spot number 2449 (Table 1; Figures 2 and 3) was characterized as a leucine aminopeptidase (LAP2) protein. LAP2 accumulation was observed in the inoculated sample of the resistant NIL only. Aminopeptidases represent plant responses to wound and pathogen stresses $[40,41]$ and their activity (in association to other peptidases) is involved in the turnover of unfolded or damaged proteins that accumulate as a result of the oxidative burst. Furthermore, the role of aminopeptidases in the genesis of bioactive peptides in animals [42] and, more recently, in plants [43] highlighted their possible contribution in defence responses signalling. The modulation of the levels of LAP2 observed was Rph15 resistance gene-dependent, consequently this protein could have a role both at the level of protein turnover, since the $R$ ph15 resistance response would most likely involve an HR-associated oxidative burst, and/or in resistance gene signalling. The fact that LAP2 is more abundant in Bowman-Rph15 line under infection reinforces the idea that protein degradation could be one of the main mechanisms contributing to resistance deployment.

\begin{tabular}{|c|c|c|c|}
\hline & & Reducing sugars & Sucrose \\
\hline & & 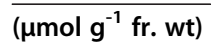 & $\overline{\left(\mathrm{mg} \mathrm{g}^{-1} \text { fr. wt }\right)}$ \\
\hline \multirow[t]{4}{*}{ NILs Bowman } & Control & $6.39^{a}$ & $30.15^{\mathrm{a}}$ \\
\hline & & \pm 0.19 & \pm 2.66 \\
\hline & Inoculated & $5.87^{\mathrm{b}}$ & $29.52^{\mathrm{a}}$ \\
\hline & & \pm 0.09 & \pm 2.58 \\
\hline \multirow[t]{4}{*}{ Bowman-Rph15 } & Control & $6.09^{a}$ & $29.02^{a}$ \\
\hline & & \pm 0.29 & \pm 2.79 \\
\hline & Inoculated & $6.85^{\beta}$ & $29.89^{a}$ \\
\hline & & \pm 0.25 & \pm 0.55 \\
\hline
\end{tabular}

The data are the means \pm SE of three experiments run in triplicate $(n=9)$. Different letters on the values indicate significant difference $P$-values $(P<0.05)$ of the t-TESTs performed comparing control and inoculated samples. 


\section{Defence responses}

Two protein spots (2886 and 2956, Table 1, Figures 2 and 3) were respectively identified as chitinase and chitinase III-like. Protein abundance significantly decreased in the inoculated samples of the resistant NIL only at $4 \mathrm{dpi}$, while in the susceptible NIL the levels of chitinases were not affected. For both chitinases, the level of accumulated proteins was however constitutively higher in mockinoculated tissues of the resistant NIL with respect to the susceptible one. This behaviour supports the possibility that a higher constitutive level of these defence proteins is associated with resistance and it operates as an early defence barriers against the pathogen infection. Similar results were found in the interaction between wheat and Septoria tritici where a higher chitinase activity, measured on whole leaf extracts, was observed in control with respect to inoculated plants during the first $7 \mathrm{dpi}$ but the enzymatic activity did not correlate well with resistance in the host or the infection course of the pathogen [44]. Plant chitinases, however, are classified into seven classes (IVII), on the basis of their structure, substrate specificity, mechanisms of catalysis, and sensitivity to inhibitors, with several members for each class $[45,46]$. Therefore it cannot be excluded that in the present work only two specific members of this class of defence proteins with peculiar roles in defence were detected.

\section{Secondary metabolism}

Spot 2613 was identified as a flavonoid 7-O-methyltransferase and the production of this protein was enhanced in infected leaves of the resistant NIL while in the susceptible NIL infection resulted in a significant down accumulation of the protein (Figures 2 and 3). This enzyme, that accumulated faster in incompatible interactions between barley and powdery mildew with respect to compatible interactions, was demonstrated to preferentially catalyze the methylation of the flavone apigenin, most likely leading to the production of phytoalexins [47]. Since methylated flavonoids have been found to have more antifungal activity than their unmethylated precursors $[48,49]$, it is plausible that the protein accumulation in Bowman-Rph15 represents a resistance gene-mediated defence response coupled to pathogen recognition, while in the susceptible NIL a successful leaf rust colonization is associated to the suppression of defence responses leading to reduction of 7-O-methyltransferase protein. Several fungal pathogens demonstrate to secrete protein effectors capable in suppressing resistance gene-based and basal defence responses [50-53]; it is therefore possible that P. hordei secreted effectors contribute to pathogen proliferation and disease development during the interaction with the susceptible NIL.

\section{Transcript analysis and correlation with proteomic data}

Eight genes involved in protein accumulation changes were evaluated at the transcription level by quantitative RT-PCR (qRT-PCR) using RNAs obtained from inoculation time course experiments that included also the inoculations time points used for proteomics analyses (Figure 5).

No or weak correlations between mRNA and protein levels were observed for the LAP2, ATP synthase and SuSy. For the last gene, only a weak correlation with the proteomic data was observed in Bowman-Rph15 being SuSy transcription up regulated until 3 dpi but then down regulated. This transcriptional response is coherent with both the observed increase of Susy protein (Figure 3) and reducing sugars (Table 2) at $4 \mathrm{dpi}$. In Bowman, SuSy gene expression increased from 3 to 4 dpi suggesting a delayed plant response to the fungus. Nevertheless, bibliographic data indicate that pathogen responsiveness of SuSy transcription is highly variable ranging from down regulation during a barley-B. graminis f. sp. tritici non-host interaction [54] to enhanced transcription observed in Arabidopsis plants infected with Plasmodiophora brassicae [55] and in phytoplasmainfected grape plants [56].

In agreement with the proteomic data, expression of RuACS and AGPPase genes decreased at 3 to $4 \mathrm{dpi}$, while transcript levels of the two chitinase genes tested decreased in the resistant NIL starting from 3 dpi. Proteomics and transcription analyses both suggested an up-regulation of flavonoid 7-O-methyltransferase in Bowman-Rph15 after leaf rust infection while the gene transcription was repressed by pathogen infection in the susceptible NIL. An up-regulation for the flavonoid 7-O-methyltransferase gene was observed also during a transcript profiling study of the broad spectrum racenonspecific leaf rust resistance gene Lr34 after interaction with $P$. triticina, but not in the compatible interaction or in the race-specific resistance gene $\operatorname{Lr} 1$ [5], thus supporting a possible important role of this enzyme in defence responses involving lignin biosynthesis and production of phytoalexins antimicrobial compounds [57].

In our experiments we observed that, for the time points subjected to parallel proteomics and transcriptomic analyses, $62,5 \%$ of the protein changes correlate with the transcriptomic data, since for five genes out of 8 analyzed, an agreement was observed between protein accumulation and transcriptional change at the corresponding time points. Higher level on incongruent expression between mRNAs and proteins was however frequently observed by other groups, in other species and experimental conditions [58-62] and is most likely a result of the biology of gene expression which includes various levels of regulation during protein synthesis: 


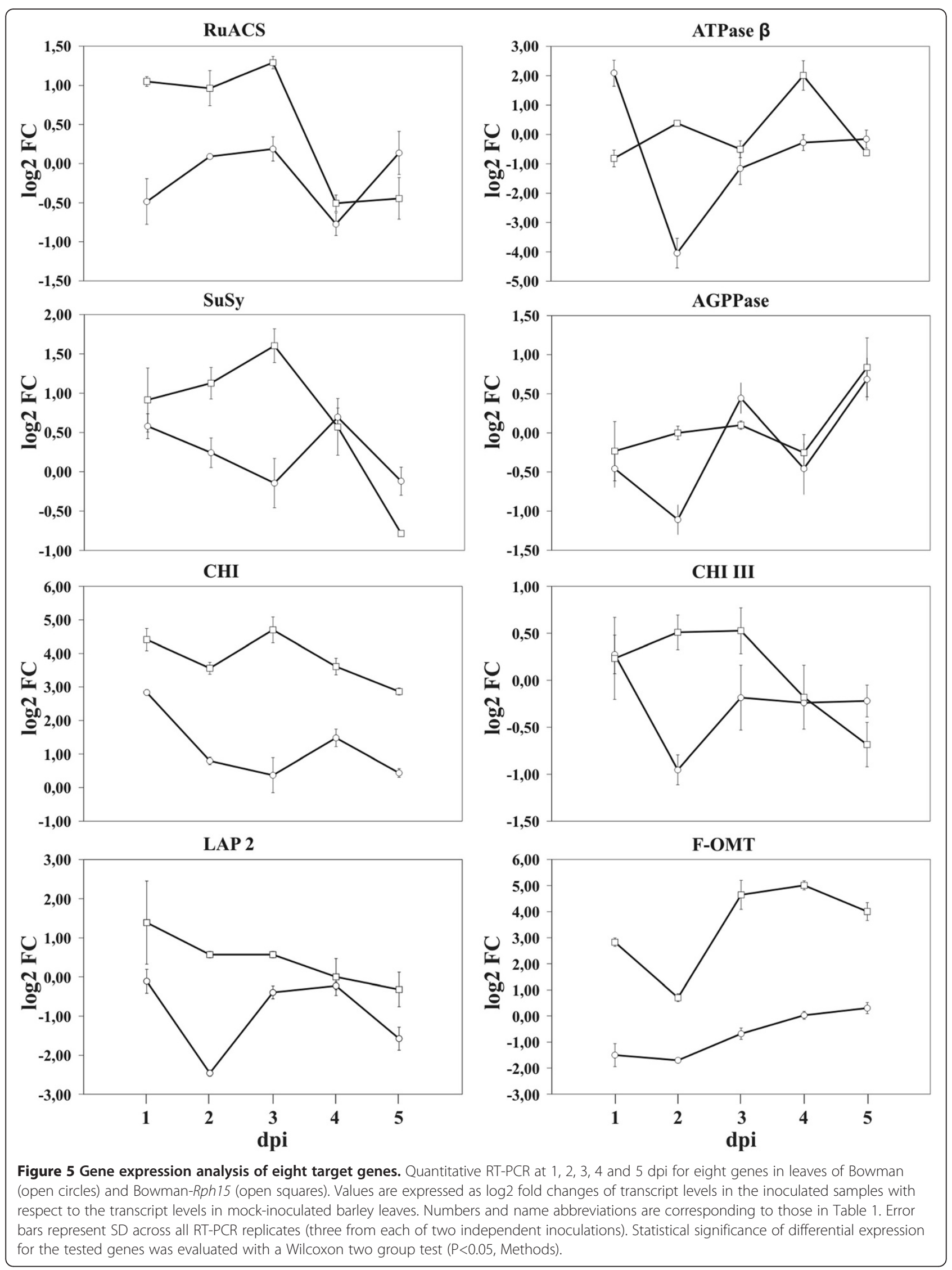


post-transcriptional, translational, and post-translational. Thus, integrated analysis of both mRNAs and proteins is crucial to gain further insights into complex biological systems.

\section{Conclusions}

In this work, proteomics and a complementary transcriptomic approaches were applied to two NILs differing for the presence of the highly effective broad spectrum Rph15 leaf rust resistance gene. The genetic materials analysed allows to relate the observed responses to the presence/absence of the resistance gene. We observed that the susceptible NIL was basically unresponsive to pathogen infection at the time points analyzed, indicating that basal defences are suppressed and/ or delayed by pathogen effectors or by the lacking of effective signalling pathways. In a study on the susceptible interaction between the leaf rust pathogen $P$. triticina and wheat, changes in proteome were identified only after 6 dpi [12], indicating that a similar delay in defence towards leaf rusts could represent a common feature of susceptible genotypes. In Bowman, a substantial transcripts down regulation in infected tissues, with respect to control samples, was observed for SuSy, LAP2 and chitinases, while down regulation of both, protein and transcripts, was observed for flavonoid 7-O-methyltransferase, supporting a suppression of defence responses by pathogen effectors. In the resistant genotype we observed a reduction of RuLC degradation products together with a down regulation of RuACS and ATP synthase. These responses could be associated to the redirection of the metabolism to sustain defence responses and, possibly, to cellular damage caused by HR responses. Protein changes for Bowman-Rph15 also supports a i) carbohydrate metabolism variation leading to a reduction in starch biosynthesis possibly connected to allocation of sugars into carbohydrate-consuming defence reactions (this hypothesis was confirmed by the quantification of reducing sugars), ii) an increase of proteins related to proteolitic activities and iii) accumulation of enzymatic proteins involved in phytoalexin and lignin production. These responses were observed in the resistant NIL only and are therefore dependent from the resistance pathways activated, upon pathogen recognition, by the Rph15-mediated resistance signalling. Since none of these changes were highlighted at $24 \mathrm{hpi}$, it can be assumed that accumulation of defence-related proteins starts in the interval between $24 \mathrm{hpi}$ and $4 \mathrm{dpi}$. In conclusion, the proteomic approach adopted, complemented with transcriptomic analysis, provided a picture about the timing, entity and the nature of differential defence responses in basal resistance and Rph15-gene mediated resistance.

\section{Methods}

\section{Fungal and plant materials}

The study was performed with barley leaf rust causal agent Puccinia hordei isolate 4, kindly provided by Prof. Brian J. Steffenson (Department of Plant Pathology, University of Minnesota, USA). The fungus urediniospores were propagated on the susceptible barley cv. Bowman and stored at $-80^{\circ} \mathrm{C}$. Inoculation was carried out after spores activation by short thermal shock at $37^{\circ} \mathrm{C}$. Active spores were implemented on Bowman barley leaves and then collected to infect barley seedlings.

Two barley (Hordeum vulgare) lines, near-isogenic (NILs) for the leaf rust resistance gene Rph15, were used in this study. The cv. Bowman is susceptible to the leaf rust isolate 4 while the line Bowman-Rph15 is resistant. These barley genotypes were kindly provided by Prof. Jerry Franckowiak (North Dakota State University, USA). All barley seedlings were grown at $16 \mathrm{~h}\left(21^{\circ} \mathrm{C}\right)$ in the light and $8 \mathrm{~h}\left(16^{\circ} \mathrm{C}\right)$ in the dark in growth chamber. Barley seedlings at the first-leaf stage were inoculated with the spores of the leaf rust isolate 4. Rust spores were mixed with talcum powder $(1: 10 \mathrm{v} / \mathrm{v})$ and used for barley leaves infection at a density of about 200 spores per $\mathrm{cm}^{2}$. Mock inoculation of the two NILs was carried out with talcum powder only. Seedlings were transferred for $24 \mathrm{~h}$ at $20^{\circ} \mathrm{C}$ in complete darkness and $100 \%$ humidity, and then placed at $20^{\circ} \mathrm{C}$ with $14 \mathrm{~h}$ in the light and 10 $\mathrm{h}$ in the dark with $60 \%$ humidity. Two biological replicates were performed for each experiment. At the end of the infection time points, leaf samples were collected and stored at $-80^{\circ} \mathrm{C}$.

\section{Protein extraction}

Barley leaf tissues were transferred into a pre-chilled mortar where they were ground to a fine powder with a pestle in liquid nitrogen and homogenized in extraction buffer (0.5 M Tris- $\mathrm{HCl} \mathrm{pH}$ 8.0, $0.7 \mathrm{M}$ sucrose, $10 \mathrm{mM}$ sodium fluoride, $1 \mathrm{mM}$ PMSF, $0.1 \mathrm{mg} \mathrm{mL}^{-1}$ Pefabloc, 0.2\% (v/v) Triton X-100, $2 \mu \mathrm{L} \mathrm{mL}{ }^{-1}$ Phosphatase Inhibitor Cocktail (Sigma), $0.2(\mathrm{v} / \mathrm{v}) \beta$ - mercaptoethanol) and PVPP 1\% on ice. Phenol extraction method of proteins was according to [63] with few modifications. Samples were centrifuged at $4500 \mathrm{~g}$ at $4^{\circ} \mathrm{C}$ for $40 \mathrm{~min}$ and the pellet was dried. The pellet was solubilized in isoelectrofocusing buffer (7 M Urea, 2 M Thiourea, 3\% w/v CHAPS, 1\% w/v NP40, 50 $\mathrm{mM} \mathrm{DTT}, 2 \% \mathrm{v} / \mathrm{v}$ ampholytes), incubated at room temperature for $1 \mathrm{~h}$ and centrifugated at $10000 \mathrm{rpm}$ for 10 minutes at room temperature. Supernatant was collected and stored at $-80^{\circ} \mathrm{C}$ until further use. Protein concentration was determined by 2D Quant Kit (GE Healthcare) and Bradford method, according to manufacturer's instructions (Biorad protein assay kit), using BSA as the standard. For each sample two different extractions were performed. 


\section{Two-dimensional electrophoresis}

Protein samples $(300 \mu \mathrm{g})$ were loaded on $\mathrm{pH} 4-7,24 \mathrm{~cm}$ IPG strips (GE Healthcare Life Sciences, USA) passively rehydrated 10 hours in $7 \mathrm{M}$ urea, $2 \mathrm{M}$ thiourea, 3\% (w/ v) CHAPS, 1\% (w/v) NP40, $10 \mathrm{mM} \mathrm{DTT,} \mathrm{0.5 \%} \mathrm{(v/v)}$ ampholytes, traces of Orange $\mathrm{G}$ before use in reswelling tray under mineral oil. IEF was conducted at $20^{\circ} \mathrm{C}$ with current limit of $75 \mu \mathrm{A} /$ strip in a Ettan IPGphor III (GE Healthcare Life Sciences, USA) following the manufacturer's protocol. After IEF, strips were equilibrated by gentle stirring for 15 minutes in an equilibration buffer (100 mM Tris- $\mathrm{HCl} \mathrm{pH}$ 6.8, $7 \mathrm{M}$ urea, $2 \mathrm{M}$ thiourea, $30 \%(\mathrm{w} / \mathrm{v})$ glycerol, $2 \%(\mathrm{w} / \mathrm{v})$ SDS) added with $0.5 \%(\mathrm{w} /$ v) DTT for disulfide bridges reduction, and for additional 15 minutes in the same equilibration buffer supplemented with $4.5 \%(\mathrm{w} / \mathrm{v})$ iodoacetamide for cysteine alkylation and $0.002 \%(\mathrm{w} / \mathrm{v})$ bromophenol blue. Seconddimensional SDS-PAGE [64] was run in $12.5 \%$ acrylamide gels using ETTAN DALTsix apparatus (GE Healthcare Life Sciences, USA). Running was conducted for $30 \mathrm{~min}$ at $5 \mathrm{~W} /$ gel followed by $15 \mathrm{~W} /$ gel, until the bromophenol blue dye front left the gel. Three technical replicates were performed for each biological replicate. Experimental pI was determined using a 4-7 linear scale over the total length of the IPG strip. $M_{r}$ values were calculated by mobility comparison with protein standard marker included in fluorescent staining (Molecular Probes, Inc.)

\section{Protein visualization and data analysis}

Silver staining: after SDS-PAGE Tris-Tricine, gels were fixed in ethanol/acetic acid solution and stained with silver nitrate as previously described [65]. Coomassie staining: proteins were visualized using colloidal Coomassie Brilliant Blue G-250 (cCBB) procedure, as previously described [66]. Images of gels stained with silver and Coomassie were scanned with an EPSON ScanMaker i900 MicroTek Scanner. Fluorescent staining: as a fluorescent stain for total proteins, the SYPRO Ruby stain (Molecular Probes), with a sensitivity of 0.5-5 ng of protein [67], was used. After 2-DE, gels were fixed twice in 50\% (v/v) methanol and 7\% (v/v) acetic acid for 30 minutes. Each single gel was immersed overnight in SYPRO Ruby and then destained in $10 \%(\mathrm{v} / \mathrm{v})$ methanol and $7 \%(\mathrm{v} / \mathrm{v})$ acetic acid and finally washed in deionized water. Fluorescent gel images were acquired on Typhoon 9210 laser scanner (GE Healthcare) at $280 \mathrm{~nm}$ and $450 \mathrm{~nm}$ excitation and $610 \mathrm{~nm}$ bandpass emission filter. Spot detection, matching and image analysis were performed using ImageMaster 2D Platinum Software 6.0 (GE Healthcare Life Sciences, USA). Automatic matching was complemented by manual matching. Spot volumes were normalized and expressed as the percentage of the total volume of all the spots present in the gels (six replicate gels for each condition).
During the analysis, only spots showing at least two-fold change in their relative volumes were considered for subsequent analyses. In order to find differentially expressed proteins, the values were $\log (\mathrm{z}+1)$ transformed and subjected to a two-way ANOVA test to verify if their changes in expression were statistically significant $(\mathrm{p}<0.05)$, using genotypes and treatments as factors. The softwares Systat and STATISTICA were used for statistical analysis.

\section{Protein in-gel digestion and mass spectrometry protein characterization}

Spots were excised from cCBB-stained 2-DE gels and ingel digested with trypsin [Sequencing grade modified Trypsin V5111, Promega, Madison] as previously described [68]. The LC-ESI-MS/MS experiments were conducted using a Surveyor (MS pump Plus) HPLC system directly connected to the Nano-ESI source of a Finnigan LCQ DECA XP MAX ion trap mass spectrometer (ThermoFisher Scientific Inc., Waltham, USA). Chromatography separations were carried out on a ZORBAX 300SB-C18 column $(75 \mu \mathrm{m}$ I.D $\times 150 \mathrm{~mm}$ length, 3.5 $\mu \mathrm{m}$ particle size, Agilent Tecnologies $\left.{ }^{\circledR}\right)$, using a linear gradient from 5 to $60 \%$ solvent B [solvent A: $0.1 \%(\mathrm{v} / \mathrm{v})$ formic acid; solvent B: ACN containing $0.1 \%(\mathrm{v} / \mathrm{v})$ formic acid] with a flow of $300 \mathrm{nl} / \mathrm{min}$. Nano-ESI was performed in positive ionization mode with spray voltage and capillary temperature set to $1.7 \mathrm{kV}$ and $180^{\circ} \mathrm{C}$, respectively. Data were collected in the full-scan and data dependent MS/MS mode with collision energy of 35\% and a dynamic exclusion window of $3 \mathrm{~min}$. Spectra were searched by TurboSEQUEST $^{\circledR}$ incorporated in BioworksBrowser 3.2 software (ThermoFisher Scientific Inc., Waltham, USA) against the Hordeum vulgare protein subset (7825 entries) and against the Hordeum vulgare EST subset (525775 entries), both downloaded from the National Center for Biotechnology Information (www.ncbi.nlm.nih.gov). The searches were carried out assuming parent ion and fragment ion mass tolerance of $\pm 2 \mathrm{Da}$ and $\pm 1 \mathrm{Da}$, respectively, one possible missed cleavage per peptide, fixed carboxyamidomethylation of cysteine and variable methionine oxidation. Positive hits were filtered on the basis of peptides scores [Xcorr $\geq 1.5$ (+1 charge state), $\geq 2.0$ ( +2 charge state $), \geq 2.5(\geq 3$ charge state), $\Delta \mathrm{Cn} \geq 0.1$, peptide probability $<1 \times 10^{-3}$ and $\mathrm{Sf} \geq 0.70$ ] [69]. If needed, identified peptides were used in protein similarity search performed against the Viridiplantae subset of the NCBI-nr database using the FASTS algorithm [70]. Physical properties of the characterized proteins were predicted by in silico tools at ExPASy (www.expasy.org) (Additional files 1 and 2).

\section{Western blot analysis}

Samples $(5 \mu \mathrm{g})$ were diluted with an equal volume of SDS-PAGE buffer [50 mM Tris-HCl ( $\mathrm{pH}$ 6.8), 4\% (w/v) 
SDS, 12\% (w/v) glycerol, 2\% (v/v) b-mercaptoethanol, and $0.01 \%(\mathrm{w} / \mathrm{v})$ bromophenol blue] and heated for $5 \mathrm{~min}$ at $90^{\circ} \mathrm{C}$, separated by SDS-PAGE using $10.0 \%$ acrylamide according to Laemmli (1970) and then electrophoretically transferred to a polyvinylidene difluoride (PVDF) filter using a semidry blotting system (NovaBlot, Pharmacia, Sweden) with a buffer containing $10 \mathrm{mM} 3-$ cyclohexylamino-1-propanesulphonic acid (CAPS, pH 11 with $\mathrm{NaOH}$ ) and $10 \%$ methanol. Filters were blocked for $1 \mathrm{~h}$ with TBS-T buffer [50 mM Tris- $\mathrm{HCl}$ (pH 7.6), 200 $\mathrm{mM} \mathrm{NaCl}$, and $0.1 \%(\mathrm{v} / \mathrm{v})$ Tween 20] supplemented with $3 \%(\mathrm{w} / \mathrm{v})$ of albumine. The TBS-T buffer was used as an incubation medium throughout the procedure. Filters were incubated overnight at $4^{\circ} \mathrm{C}$ with primary polyclonal antibodies against Rubisco large subunit using a 1:10.000 dilution (Agrisera, AS03 037). After washing with TBS-T, the filters were incubated for a further $2 \mathrm{~h}$ at room temperature with a secondary antibody (alkalinephosphatase-conjugated anti-rabbit immunoglobulin G). The blot was developed with nitroblue tetrazolium and 5-bromo-4-chloro-3-indolyl phosphate (FAST BCIP/ NBT, Sigma). Three technical replicates were performed for the hybridization analyses. Quantification of the
RuBisCO degraded forms was conducted by using the software Image Quant (Molecular Dynamic), version 5.2.

\section{RNA extraction and quantitative RT-PCR analysis}

Eight target genes identified from proteomics analysis were selected for transcriptional analysis. Total RNA was extracted from $500 \mathrm{mg}$ of frozen leaves powder of mock-inoculated and $P$. hordei-inoculated plants using TRI reagent ${ }^{\circledR}$ solution (Applied Biosystems, Foster City, CA, USA), according to manufacturer's instruction. The RNA pellet was dissolved in $100 \mu \mathrm{l}$ of autoclaved DEPC water and then stored at $-80^{\circ} \mathrm{C}$. RNA was extracted in a time course experiments from 24 hours to 5 days after pathogen inoculation. Nucleic acid quality was estimated using the Bioanalyzer software (Agilent Technologies, Santa Clara, CA, USA), while RNA concentrations were measured with a spectrophotometer (Beckman Coulter, CA, USA) and only RNA samples with an $\mathrm{A}_{260} / \mathrm{A}_{280}$ ratio in the range 1.8-2.0 were used in RT-PCR analysis. Sequences of the primers and reaction conditions used for RT-PCRs were as previously described [71]. Quantitative RT-PCR was performed using a One Step Real Time PCR System (Applied Biosystems, Foster City, CA,

Table 3 List of the genes whose transcription profile was evaluated by qRT-PCR

\begin{tabular}{|c|c|c|c|}
\hline Gene name & $\begin{array}{l}\text { Accession } \\
\text { number }\end{array}$ & Primer & $5^{\prime}-3^{\prime}$ primer sequences \\
\hline \multirow[t]{2}{*}{ Oxalate oxidase } & \multirow[t]{2}{*}{ Y14203 } & $\mathrm{F}$ & CTGGCTGTTGAAGGACACAA \\
\hline & & $\mathrm{R}$ & TGACTCCGGAAACAAGCTCT \\
\hline \multirow[t]{2}{*}{ Callose synthase } & \multirow[t]{2}{*}{ AY177665 } & $\mathrm{F}$ & CATCAAGGAATCAGCTGCAA \\
\hline & & $\underline{\mathrm{R}}$ & TCGCATGAACAAAGAGTTCG \\
\hline \multirow[t]{2}{*}{ Sucrose synthase } & \multirow[t]{2}{*}{ X65871 } & $\mathrm{F}$ & AAGCTGAAAGGCCATATCCGTT \\
\hline & & $\mathrm{R}$ & AGAATGCAGGCTGCACAAATG \\
\hline \multirow{2}{*}{$\begin{array}{l}\text { Adenosine } \\
\text { diphosphate glucose } \\
\text { pyrophosphatase }\end{array}$} & \multirow[t]{2}{*}{ AJ291451 } & $\mathrm{F}$ & TCATCAGCTCСTCCTCCAAC \\
\hline & & $\mathrm{R}$ & TGCCACCGTTGTACTGGTAG \\
\hline \multirow[t]{2}{*}{ Flavonoid 7-O-methyltransferase } & \multirow[t]{2}{*}{ X77467 } & $\mathrm{F}$ & CGAGGCTITCCCTTATGTCA \\
\hline & & $\mathrm{R}$ & ACTCCATCATGTCACCAGCA \\
\hline \multirow[t]{2}{*}{ Leucine Aminopeptidase 2} & \multirow[t]{2}{*}{ AK248195 } & $\mathrm{F}$ & TCGGGCTCACCAAGGCCAACG \\
\hline & & $\mathrm{R}$ & GAGGATGTCGCCCTTCCAGTCG \\
\hline \multirow[t]{2}{*}{ Rubisco activase } & \multirow[t]{2}{*}{ M55447 } & $\mathrm{F}$ & TCCAAAAACTTCATGACCCTGC \\
\hline & & $\mathrm{R}$ & CGAACACAAGCTCACACTGGAA \\
\hline \multirow[t]{2}{*}{ ATP synthase B chain } & \multirow[t]{2}{*}{ EU963772 } & $\mathrm{F}$ & AGAAGGCCGCACTGTTTGACT \\
\hline & & $\underline{\mathrm{R}}$ & CATCCATGAACTTGCCTAGCG \\
\hline \multirow[t]{2}{*}{ Chitinase } & \multirow[t]{2}{*}{ X78672 } & $\mathrm{F}$ & GCCACGTCTCCACCCTACTA \\
\hline & & $\mathrm{R}$ & ACCGTTCTGAAGGACACCAC \\
\hline \multirow[t]{2}{*}{ Chitinase III } & \multirow[t]{2}{*}{ AK251032 } & $\mathrm{F}$ & TAAGCTGTGCCGACTGAATG \\
\hline & & $\mathrm{R}$ & CACTGCAAACCACAACATCC \\
\hline \multirow[t]{2}{*}{ Actin } & \multirow[t]{2}{*}{ AJ234400 } & $\mathrm{F}$ & ACCTCGCTGGGCGTGACCTAACTG \\
\hline & & $\mathrm{R}$ & TGGTCTATGGATTCCAGCAGCTTCC \\
\hline
\end{tabular}


USA) and 100 ng of total RNA per reaction. Primers were designed using Primer3 software (http://frodo.wi. mit.edu/primer3/) (Table 3) and primers specificity was evaluated by blasting primer sequences against the NCBI database. The barley $\beta$-actin constitutively expressed gene was used as reference gene for normalization. Standard variation in all samples was lower than $10 \%$. PCR amplifications were performed in $25 \mu \mathrm{l}$ of final volumes containing 2x QuantiFast SYBR ${ }^{\circledR}$ Green Master Mix (Qiagen, Hiden, Germany) and including ROX $^{\mathrm{mm}}$ as passive reference dye, $400 \mu \mathrm{M}$ each primer and $0.25 \mathrm{U} / \mu \mathrm{l}$ Multiscribe $^{\mathrm{Tx}}$ Reverse Transcriptase (Applied Biosystems). Three technical replicates for each of the two biological replicates were performed. Relative gene expression was calculated using the $2^{-\Delta \Delta C t}$ method [72]. For all the genes tested by quantitative RT-PCR, a Wilcoxon two group test $[73,74]$ was used to analyze the $\Delta \mathrm{Ct}$ values $\left(\mathrm{Ct}_{\text {target }}-\mathrm{Ct}{ }_{\text {Bact }}\right)$ in infected and un-infected samples at each time point of inoculation. Data from two biological replicates with three technical replicates each were used for the analysis. In all the time points where an increased or decreased transcription of the genes in response to pathogen inoculation was observed, the test yielded $P$-values $<0.05$, indicating that $\Delta \Delta \mathrm{Ct}$ was significantly different from 0 and that there was a significant effect. No statistically different $\Delta \Delta \mathrm{Ct}$ values were observed for samples in which no transcriptional variations were detected by quantitative RT-PCR.

\section{Determination of reducing sugars and sucrose}

Reducing sugars, sucrose and amino acids were extracted by homogenizing frozen tissues in 5 volumes of ice-cold 0.5 M perchloric acid (PCA). The homogenate was centrifuged for $20 \mathrm{~min}$ at $11,000 \mathrm{~g}$ at $4^{\circ} \mathrm{C}$ and the resulting pellet was washed with the same volume of PCA and then centrifuged again in the same conditions. $\mathrm{KOH}$ was added to the collected supernatant (to $\mathrm{pH}$ 7.6) to remove excess PCA. Reducing sugars were measured according to the colorimetric method by [75]. Total soluble sugars were determined by the same method boiling an aliquot of PCA extract for $1 \mathrm{~h}$ before neutralization. Sucrose was estimated from the difference between total soluble and reducing sugars.

\section{Additional files}

Additional file 1: Caption of Additional file 2.

Additional file 2: Data on protein identification by LC-ESI-MS/MS and bioinformatic analysis. Table shows the sequence of the peptides identified by MS/MS and the statistical information related to peptides, proteins and alignment analyses.

\section{Abbreviations}

NILs: Near isogenic lines; RuLC: Ribulose bisphosphate carboxylase large chain; RuACS: Ribulose bisphosphate carboxylase/oxygenase activase A chloroplastic; ATPase $\beta$ : ATP synthase $\beta$ chain; SuSy: Sucrose synthase; AGPPase: Adenosine diphosphate glucose pyrophosphatase; LAP 2: Leucine aminopeptidase 2 chloroplastic; CHI: Chitinase; CHI III: Chitinase III-like protein; F-OMT: Flavonoid 7-O-methyltransferase.

\section{Competing interests}

The authors declare any competing financial or other interest in relation to this work.

\section{Authors' contributions}

GV, LE and LC planned and supervised the work. LB carried out protein extraction, 2-DE gel analysis, statistical analysis, transcriptional analysis and drafted the MS. BP carried out protein characterization by LC-ESI-MS/MS, analyzed the MS data. ASN helped to perform 2-DE gel analysis and carried out statistical analysis. BP, ASN and LE carried out sugar and Western blot analyses. All the authors contributed to the final version of the manuscript. All authors read and approved the final manuscript.

\section{Acknowledgements}

This research was partially supported by the Italian Ministero per le Politiche Agricole, Alimentari e Forestali, MiPAF, in the framework of "PROTEOSTRESS" and "RESPAT" projects.

\section{Author details}

'CRA-Consiglio per la ricerca e la sperimentazione in agricoltura, Genomics Research Centre, Via S. Protaso 302, Fiorenzuola d'Arda, PC I-29017, Italy. ${ }^{2}$ Dipartimento di Scienze agrarie ambientali - Produzione - Territorio Agroenergia (Di.S.A.A), University of Milan, via Celoria 2, Milano I-20133, Italy. ${ }^{3}$ CRA-Consiglio per la ricerca e la sperimentazione in agricoltura, Rice Research Unit, S.S. 11 to Torino, Km 2,5, Vercelli 13100, Italy.

Received: 27 April 2012 Accepted: 9 November 2012

Published: 20 November 2012

\section{References}

1. Weerasena JS, Steffenson BJ, Falk AB: Conversion of an amplified fragment length polymorphism marker into a co-dominant marker in the mapping of the Rph15 gene conferring resistance to barley leaf rust, Puccinia hordei Otth. Theor Appl Genet 2004, 108:712-719.

2. Cotterill PJ, Rees RG, Platz GJ: Response of Australian barley cultivars to leaf rust (Puccinia hordei). Aust J Exp Agric 1994, 34:783-788.

3. Webb CA, Fellers JP: Cereal rust fungi genomics and the pursuit of virulence and avirulence factors. FEMS Microbiol Lett 2006, 264:1-7.

4. Heath MC: Signalling between pathogenic rust fungi and resistant or susceptible host plants. Annals of Bot 1997, 80:713-720.

5. Bolton MD, Kolmer JA, Garvin DF: Wheat leaf rust caused by Puccinia triticina. Mol Plant Pathol 2008, 9:563-575.

6. Niks RE, Walther $U$, Jaiser $H$, Martinez F, Rubiales $D$, Anderson $O$, Flath $K$, Gymer P, Heinrichs F, Jonsson R, Kuntze L, Rasmussen M, Richter E: Resistance against barley leaf rust Puccinia hordei in west-European spring barley germplasm. Agronomie 2000, 20:769-782.

7. Marcel TC, Aghnoum R, Durand J, Varshney RK, Niks RE: Dissection of the barley 2L1.0 region carrying the "Laevigatum" quantitative resistance gene to leaf rust using near-isogenic lines (NIL) and subNIL. Mol Plant Microbe Interact 2007, 20:1604-1615.

8. Golegaonkar PG, Singh D, Park RF: Evaluation of seedling and adult plant resistance to Puccinia hordei in barley. Euphytica 2009, 166:183-197.

9. Golegaonkar PG, Karaoglu H, Park RF: Molecular mapping of leaf rust resistance gene Rph14 in Hordeum vulgare. Theor Appl Genet 2009, 119:1281-1288.

10. Chen X, Hackett CA, Niks RE, Hedley PE, Booth C, Druka A, Marcel TC, Vels A Bayer M, Milne I, Morris J, Ramsay L, Marshall D, Cardle L, Waugh R: An eQTL analysis of partial resistance to Puccinia hordei in barley. PLoS One 2010, 5:e8598.

11. Chen X, Niks RE, Hedley PE, Morris J, Druka A, Marcel TC, Vels A, Waugh R: Differential gene expression in nearly isogenic lines with QTL for partial resistance to Puccinia hordei in barley. BMC Genomics 2010, 11:629.

12. Rampitsch C, Bykova NV, McCallum B, Beimcik E, Ens W: Analysis of the wheat and Puccinia triticina (leaf rust) proteomes during a susceptible host-pathogen interaction. Proteomics 2006, 6:1897-1907. 
13. Lin KC, Rushnell WR, Smith AG, Szabo LJ: Temporal accumulation patterns of defence response gene transcripts in relation to resistant reactions in oat inoculated with Puccinia graminis. Physiol Mol Plant Pathol 1998, 52:95-114.

14. Sellam MA, Wilcoxson RD: Development of Puccinia graminis f. sp. tritici on resistant and susceptible barley cultivars. Phytopathol 1976, 66:667-668

15. Zhou F, Zhang Z, Gregersen PL, Mikkelsen JD, de Neergaard E, Collinge DB, Thordal-Christensen $\mathrm{H}$ : Molecular characterization of the oxalate oxidase involved in the response of barley to powdery mildew fungus. Plant Physiol 1998, 117:33-41.

16. Schulze-Lefert P: Knocking on the heaven's wall: pathogenesis of and resistance to biotrophic fungi at the cell wall. Curr Opin Plant Biol 2004, 7:377-383.

17. Feller $U$, Anders I, Mae T: Rubiscolytics: fate of Rubisco after its enzymatic function in a cell is terminated. J Exp Bot 2008, 59:1615-1624.

18. Spreitzer RJ, Salvucci ME: Rubisco: structure, regulatory interactions and possibilities for a better enzyme. Annu Rev Plant Biol 2002, 53:449-475.

19. Zhou W, Eudes F, Laroche A: Identification of differentially regulated proteins in response to a compatible interaction between the pathogen Fusarium graminearum and its host, Triticum aestivum. Proteomics 2006, 6:4599-4609.

20. Donnelly BE, Madden RD, Ayoubi P, Porter DR, Dillwith JW: The wheat (Triticum aestivum L.) leaf proteome. Proteomics 2005, 5:1624-1633.

21. Valledor $L$, Jorrín JV, Rodríguez JL, Lenz C, Meijón M, Rodríguez R, Cañal MJ: Combined proteomic and transcriptomic analysis identifies differentially expressed pathways associated to Pinus radiata needle maturation. J Proteome Res 2010, 9:3954-3979.

22. Boccara M, Schwartz W, Guiot E, Vidal G, De Paepe R, Dubois A, Boccara AC: Early chloroplastic alterations analysed by optical coherence tomography during a harpin-induced hypersensitive response. Plant 2007, 50:338-346.

23. Yu CL, Yan SP, Wang CC, Hu HT, Sun WN, Yan CQ, Chen JP, Yang L: Pathogenesis-related proteins in somatic hybrid rice induced by bacterial blight. Phytochem 2008, 69:1989-1996.

24. Tsunezuka H, Fujiwara M, Kawasaki T, Shimamoto K: Proteome analysis of programmed cell death and defense signaling using the rice lesion mimic mutant cdr2. Mol Plant Microbe Interact 2005, 18:52-59.

25. Mahmood T, Jan A, Kakishima M, Komatsu S: Proteomic analysis of bacterial-blight defense-responsive proteins in rice leaf blades. Proteomics 2006, 6:6053-6065.

26. Kang SG, Matin MN, Bae H, Natarajan S: Proteome analysis and characterization of phenotypes of lesion mimic mutant spotted leaf 6 in rice. Proteomics 2007, 7:2447-2458.

27. Portis AR, Li C, Wang D, Salvucci ME: Regulation of Rubisco activase and its interaction with Rubisco. J Exp Bot 2008, 59:1597-1604.

28. Tucker WC, Du Z, Hein R, Gromet-Elhanan Z, Ritcher ML: Role of the ATP synthase a-subunit in conferring sensitivity to tentoxin. Biochem 2001, 26:7542-7548.

29. Garavaglia BS, Thomas L, Gottig N, Dunger G, Garofalo CG, Daurelio LD, Ndimba B, Orellano EG, Gehring C, Ottado J: A eukaryotic-acquired gene by a biotrophic phytopathogen allows prolonged survival on the host bby counteracting the shut-down of plant photosynthesis. PLoS One 2010, 5:e8950.

30. Margaria P, Palmano S: Response of the Vitis vinifera L. Cv. 'Nebbiolo' proteome to flavescence dorée phytoplasma infection. Proteomics 2011, 11:212-224.

31. Swarbrick PJ, Schulze-Lefert P, Scholes JD: Metabolic consequences of susceptibility and resistance (race-specific and broad-spectrum) in barley leaves challenged with powdery mildew. Plant Cell Env 2006, 29:10611076.

32. Bilgin DD, Zavala JA, Zhu J, Clough SJ, Ort DR, Delucia EH: Biotic stress globally downregulates photosynthesis genes. Plant Cell Env 2010, 33:1597-1613.

33. Bolton MD: Primary metabolism and plant defence - fuel for the fire. Mol Plant-Microbe Interact 2009, 22:487-497.

34. Nguyen-Quoc B, Foyer $\mathrm{CH}$ : A role for 'futile cycles' involving invertase and sucrose synthase in sucrose metabolism of tomato fruit. J Exp Bot 2001, 52:881-889.

35. Shoresh M, Harman GE: The molecular basis of shoot responses of maize seedlings to Trichoderma harzianum T22 inoculation of the root: a proteomic approach. Plant Physiol 2008, 147:2147-2163.
36. Essmann J, Bones $\mathrm{P}$, Weis W, Scharte J: Leaf carbohydrate metabolism during defense. Plant Sign Behav 2008, 3:885-887.

37. Berger S, Sinha AK, Roitsch T: Plant physiology meets phytopathology: plant primary metabolism and plant-pathogen interactions. J Exp Bot 2007, 58:4019-4026.

38. Baroja-Fernández E, Munõz FJ, Zandueta-Criado A, Morán-Zorzano MT, Viale AM, Alonso-Casajús N, Pozueta-Romero J: Most of ADP glucose linked to starch biosynthesis occurs outside the chloroplast in source leaves. Proc Natl Acad Sci USA 2004, 35:13080-13085.

39. Rodríguez-López M, Baroja-Fernández E, Zandueta-Criado A, PozuetaRomero J: Adenosine diphosphate glucose pyrophosphatase: A plastidial phosphodiesterase that prevents starch biosynthesis. Proc Natl Acad Sci USA 2000, 97:8705-8710.

40. Yang L, Mickelson S, See D, Blake TK, Fischer AM: Genetic analysis of the function of the major leaf proteases in barley (Hordeum vulgare L.) nitrogen remobilization. J Exp Bot 2004, 55:2607-2616.

41. Chao WH, Pautot V, Holzer FM, Walling LL: Leucine aminopeptidases: the ubiquity of LAP-N and the specificity of LAP-A. Planta 2000, 210:563-573.

42. Shrimpton CN, Smith Al, Lew RA: Soluble metalloendopeptidases and neuroendocrine signalling. Endocr Rev 2002, 23:647-664.

43. Srivastava R, Liu J-X, Howell SH: Proteoltyic processing of a precursor protein for a growth-promoting peptide by a subtilisin serine protease in Arabidopsis. Plant J 2008, 56:219-227.

44. Shetty NP, Jensen JD, Knudsen A, Finnie C, Geshi N, Blennow A, Collinge DB, Jørgensen HJL: Effects of $\beta$-1,3-glucan from Septoria tritici on structural defence responses in wheat. J Exp Bot 2009, 60:4287-4300.

45. Collinge DB, Kragh KM, Mikkelsen JD, Nielsen KK, Rasmussen U, Vad K: Plant chitinases. Plant J 1993, 3:31-40.

46. Grover A: Plant Chitinases: Genetic Diversity and Physiological Roles. Critical Rev Plant Sci 2012, 31:57-73.

47. Christensen AB, Gregersen PL, Olsen CE, Collinge DB: A flavonoid 7-Omethyltransferase is expressed in barley leaves in response to pathogen attack. Plant Mol Biol 1998, 36:219-227.

48. Kodama O, Miyakawa J, Akatsuka T, Kiyosawa S: Sakuranetin, a flavanone phytoalexin from ultraviolet-irradiated rice leaves. Phytochem 1992, 11:3807-3809.

49. VanEtten HD, Matthews DE, Matthews PS: Phytoalexin detoxification: Importance for pathogenicity and practical implications. Annu Rev Phytopath 1989, 27:143-164.

50. Dou D, Kale SD, Wang $X$, Chen $Y$, Wang Q, Wang X, Jiang RH, Arredondo FD, Anderson RG, Thakur PB, McDowell JM, Wang Y, Tyler BM: Conserved $\mathrm{C}$-terminal motifs required for avirulence and suppression of cell death by Phytophthora sojae effector Avr1b. Plant Cell 2008, 20:1118-1133.

51. He P, Shan L, Sheen J: Elicitation and suppression of microbe-associated molecular pattern-triggered immunity in plant-microbe interactions. Cell Microbiol 2007, 9:1385-1396.

52. Houterman PM, Spejer D, Dekker HL, De Koster CG, Cornelissen BJC, Rep M: The mixed xylem sap proteome of Fusarium oxysporum-infected tomato plants. Mol Plant Pathol 2007, 8:215-221.

53. Houterman PM, Cornelissen BJC, Rep M: Suppression of plant resistance gene-based immunity by a fungal effector. PLoS Pathogens 2008, 4:e1000061.

54. Zellerhoff N, Himmelbach A, Dong W, Bieri S, Schaffrath U, Schweizer P: Nonhost resistance of barley to different fungal pathogens is associated with largely distinct, quantitative transcriptional responses. Plant Physiol 2010, 152:2053-2066.

55. Siemens J, Keller I, Sarx J, Kunz S, Schuller A, Nagel W, Schmulling T, Parniske M, Ludwig-Muller J: Transcriptome analysis of Arabidopsis clubroots indicate a key role for cytokinins in disease development. $\mathrm{Mo}$ Plant-Microbe Interact 2006, 19:480-494.

56. Hren M, Ravnikar M, Brzin J, Ermacora P, Carraro L, Bianco PA, Casati P, Borgo M, Angelini E, Rotter A, Gruden K: Induced expression of sucrose synthase and alcohol dehydrogenase I genes in phytoplasma-infected grapevine plants grown in the field. Plant Pathol 2009, 58:170-180.

57. Lam KC, Ibrahim RK, Behdad B, Dayanandan S: Structure, function, and evolution of plant O-methyltransferases. Genome 2007, 50:1001-1013.

58. Gygi SP, Rochon Y, Franza BR, Aebersold R: Correlation between protein and mRNA abundance in yeast. Mol Cell Biol 1999, 19:1720-1730.

59. Chen G, Gharib TG, Huang CC, Taylor JMG, Misek DE, Kardia SLR, Giordano TJ, lannettoni MD, Orringer MB, Hanash SM, Beer DG: Discordant Protein 
and mRNA Expression in Lung Adenocarcinomas. Mol Cell Proteomics 2002, 1:304-313.

60. Tian Q, Stepaniants SB, Mao M, Weng L, Feetham MC, Doyle MJ, Yi EC, Dai H, Thorsson V, Eng J, Goodlett D, Berger JP, Gunter B, Linseley PS, Stoughton RB, Aebersold R, Collins SJ, Hanlon WA, Hood LE: Integrated Genomic and Proteomic Analyses of Gene Expression in Mammalian Cells. Mol Cell Proteomics 2004, 3:960-969.

61. Yin L, Tao Y, Zhao K, Shao J, Li X, Liu3 G, Liu S, Zhu L: Proteomic and transcriptomic analysis of rice mature seed-derived callus differentiation. Proteomics 2007, 7:755-768.

62. Sánchez-Pons N, Irar S, García-Muniz N, Vicient CM: Transcriptomic and proteomic profiling of maize embryos exposed to camptothecin. BMC Plant Biol 2011, 11:91.

63. Isaacson T, Damasceno CMB, Saravanan RS, He Y, Catalá C, Saladié M, Rose JKC: Sample extraction techniques for enhanced proteomic analysis of plant tissue. Nat Protoc 2006, 1:769-774.

64. Laemmli UK: Cleavage of structural proteins during the assembly of the head of bacteriophage T4. Nature 1970, 227:680-685.

65. Heukeshoven J, Dernick R: Improved silver staining procedure for fast staining in PhastSystem Development Unit. I. Staining of sodium dodecyl sulfate gels. Electrophoresis 1988, 9:28-32.

66. Neuhoff $\mathrm{V}$, Arold N, Taube D, Ehrhardt W: Improved staining of proteins in polyacrylamide gels including isoelectric focusing gels with clear background at nanogram sensitivity using Coomassie Brilliant Blue G-250 and R-250. Electrophoresis 1988, 9:255-262.

67. Miller I, Crawford J, Gianazza E: Protein stains for proteomic applications: Which, when, why? Proteomics 2006, 6:5385-5408.

68. Prinsi B, Negri AS, Pesaresi P, Cocucci M, Espen L: Evaluation of protein pattern changes in roots and leaves of Zea mays plants in response to nitrate availability by two-dimensional gel electrophoresis analysis. BMC Plant Biol 2009, 9:113.

69. Eng JK, McCormack AL, Yates JR: III: An approach to correlate tandem mass spectral data of peptides with amino acid sequences in a protein database. J Am Soc Mass Spec 1994, 5:976-989.

70. Mackey AJ, Haystead TAJ, Pearson WR: Getting more from less: algorithms for rapid protein identification with multiple short peptide sequences. Mol Cell Proteomics 2002, 1:139-147.

71. Haegi A, Bonardi V, Dall'Aglio E, Glissant D, Tumino G, Collins NC, Bulgarelli D, Infantino A, Stanca AM, Delledonne M, Valè G: Histological and molecular analysis of Rdg2a barley resistance to leaf stripe. Mol Plant Pathol 2008, 9:463-478.

72. Livak KJ, Schmittgen TD: Analysis of relative gene expression data using Real-Time quantitative PCR and the $2^{-\Delta \Delta C t}$ method. Methods 2001, 25:402-408.

73. Hollander M, Wolfe DA: Nonparametric Statistical Methods. New York: John Wiley and Sons; 1973:503.

74. Yuan JS, Reed A, Chen F, Stewart CN Jr: Statistical analysis of real time PCR data. BMC Bioinforma 2006, 7:85.

75. Nelson NA: A photometric adaptation of the Somogy method for the determination of glucose. JBC 1944, 153:375-384.

doi:10.1186/1471-2164-13-642

Cite this article as: Bernardo et al: Proteomic characterization of the $R p h 15$ barley resistance gene-mediated defence responses to leaf rust. BMC Genomics 2012 13:642.

\section{Submit your next manuscript to BioMed Central and take full advantage of:}

- Convenient online submission

- Thorough peer review

- No space constraints or color figure charges

- Immediate publication on acceptance

- Inclusion in PubMed, CAS, Scopus and Google Scholar

- Research which is freely available for redistribution

Submit your manuscript at www.biomedcentral.com/submit 